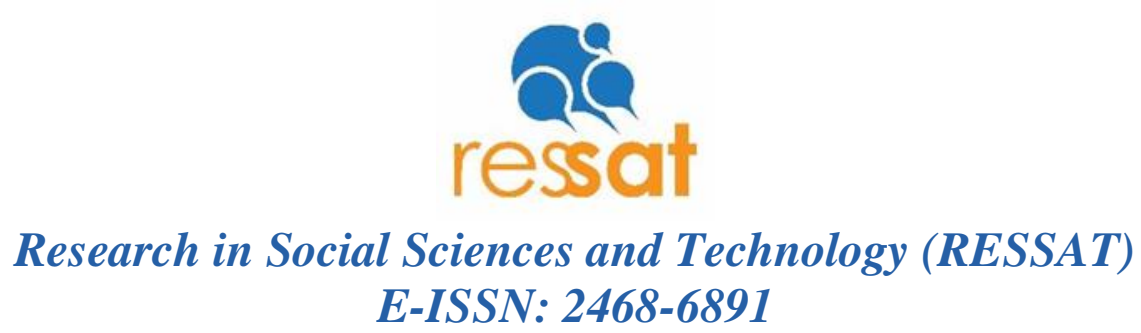

\title{
Palestinian Teachers' Views on the Factors That Limit Students' Creativity and Some Possible Strategies to Overcome Them
}

\author{
Ahmed Raba' ${ }^{1}$ \& Hussam Herzallah ${ }^{2}$
}

\begin{abstract}
This study seeks to investigate the degree of enhancing creative thinking skills in the English for Palestine and math curricula from the teachers of English and math perspectives. To accomplish this aim, the researchers used a 20-item questionnaire and a 5-question interview. Findings of the research showed that the degree of using creative thinking in schools and curricula is low and inadequate. In the light of these findings, the researchers recommended divergent methods of teaching, adequate training for teachers and students on different techniques and the inclusion of activities in the curricula to improve students' creative thinking.
\end{abstract}

Key words: Creative Thinking Skills, English and Math Curricula.

\section{Introduction}

It worth raising a crucial issue which is knowledgeable thinkers are more likely to achieve success, solve problems and make correct decisions for life than ordinary people. The ability to think clearly and rationally is essential whatever human beings choose to do, so thinking clearly and systematically is of great importance in every field of life especially in education field. Teaching thinking skills is basic due to the flux of knowledge available in all fields. Thinking skills provide the necessary tools to address this flood of renewable knowledge that has been witnessed in our modern world. Via developing this skill, learners can differentiate themselves from others. They help learners to promote imagination and concentration. They also give them the potentials to view the world differently. (Jarwan, 2007: p.60). As indicated by (Larsen, 2002: p.55), the new challenge for the development of educational and pedagogical curricula is that it needs to provide programs on teaching thinking process to all; therefore, educators in recent years strive to create strategies to develop thinking for all individuals to solve unexpected problems. That is schools and curricula must provide students with proper tools and proper

\footnotetext{
${ }^{1}$ Associate Professor-An-Najah National University- Faculty of Education and Teacher Trainingahmedm@najah.edu

${ }^{2}$ Associate professor-Al-Quds Open University-Tulkarm Branch-hhirzalla@qou.edu
} 
thinking skills that they can use to deal with multiple and diverse situations that they may encounter in school and in life as well. Friesen and Jardine (2010), Freire (1970), Cotton, (1991).

The urgent need for high thinking skill is a must for all in the current digital era with Web 2.0 and other forms of technology having become an inseparable part of schools, learning styles are changing rapidly, forcing learners to carry a transformational change in their pockets in the form of powerful multimedia handheld devices (Chen, 2010). These digital technologies have changed the traditional pedagogical paradigm, by enabling educators to reach their students directly and to revolutionize their learning experiences, which poses a lot of challenges in the way of thinking both critically and creatively (Yücel, et al, 2010; Tarman, Baytak, \& Duman, 2015). Therefore, it is time to reflect on whether our pedagogical approaches are congruent with the learning styles of this generation. Learners will not be working on routine information seeking and problem solving, but will forge new and dynamic relationships, and tackle novel challenges with sophisticated technology (McWilliams, 2008). The challenge for educators is thus to move beyond the convergent thinking tasks of multiple-choice and recall assignments that are dominating educational practices (Tarman \& Chigisheva, 2017; Tarman, 2017). Based on these important grounds, the researchers conducted this study which showed the importance of creative thinking in teaching via determining the obstacles that limit the extent to which creative thinking is practiced and the elements that lack creativity in our schools' curricula. Pragmatically, it aims to give recommendations to deal with these obstacles. The number of studies concerned with creativity in the Palestinian schools is not adequate. Since we have a low level of creativity in our schools, studies like this should minimize the gaps that prevent the creative thinking elements in curricula

Unfortunately, Palestinian schools do not enhance creative thinking at a satisfactory level. The current curriculum and teaching strategies are reluctant to give up rote memorization and spoon feeding. Curricula do not include creative materials and questions. Moreover, schools do not give teachers autonomy on deciding what to teach in their classes. They are obliged to follow their school's system, the predetermined textbooks and lesson plans. There is no place for creative activities that allow students to deal with new situations in effective ways. Teacher- centered education in our schools limit the extent of students' creativity. Teachers supply students with the possible questions to be asked in the exams, and they leave no room for students' creativity in 
answering them and dealing with new authentic situations. Students are like robots, expected to give predetermined answers to certain questions. This restricted systematic educational process suppresses creativity, imagination and innovation. Instead of supporting students' abilities to merely memorize paragraphs, rules and techniques, teaching policies that allow multiple answers, analysis and representations of the materials must be developed. (Hamdona, 2007Jarwan, 2007, Ayat 2012, Hammad, 2014 and Romahi and Issa 2010)

\section{Research problem}

The researchers have noticed that students do not seem to have characteristics of creative thinking when dealing with subjects such as English and Math. They do not have the ability to think out of the box. This may be due to the fact that the Palestinian educational system limits the extent of using creative thinking because the curricula used in the Palestinian schools depend heavily on rote memorization and predetermined syllabi. Dajani and McLaughlin (2009) Ayat (2012) and Raba'2014 and Romahi and Issa (2010). Moreover, schools and teachers neglect important creative activities. This research aims to illuminate the aspects that restrict creativity in the teaching process and seeks to have solutions.

\section{Literature review}

A lot of research was carried out to provide feedback to textbooks designers and educationists because of the importance of thinking skills as an integral part in the teaching and learning process. For the sake of clarity and systematicity, the researchers divided this section into three subsections where they showed definition of creative thinking, research findings about creative thinking in general, creative thinking in Palestinian curricula and schools, and creative thinking in math and English lessons and finally, the researcher end this section with the research questions research.

\section{Definition and research findings about creative thinking in general:}

Creative thinking was defined as the skill to come up with "original, inventive and novel ideas" (Cropley, 1992, p. 6). His definition about creativity revolves around authenticity and innovation. Not much different from Cropley, Sternberg (1999) referred to creative thinking as the ability to manage situations and solve problems in various ways, to formulate new solutions without neglecting the original appropriate ones. According to these definitions creativity would help overcome the dominant way of teaching seeking to develop one answer and one way of thinking from students. These definitions encourage the multiplicity of opinions and solutions. To sum up, "Critical thinking is self-guided, self-disciplined thinking which attempts to reason at the highest level of quality in a fair-minded way. People who think critically consistently attempt to live rationally, reasonably, empathically. They are keenly aware of the inherently flawed nature of human thinking when left unchecked." (Elder, 2007:3)

When dealing with creativity, there is a tendency to separate and differentiate creativity as a product and process (Lubart,1990). With reference to creativity as product, Magno (2009) states 
that "creativity is a product of an executed imagination" (p. 10). A creative product is judged by its genuineness and benefit (Barron, 1955; MacKinnon, 1962). A creative product is considered as a surprising and unexpected result. Csikszentmihalyi (1996) argues that a creative product is the result of analyzing information with regard to the social and cultural surroundings. Discarding the social and cultural facts does not yield applicable and reasonable solutions. Creative thinking requires imagination and thinking out of the box in different ways, but that doesn't mean being illogical.

In regard to the creativity process, Torrance and Myers (1970) illustrate that the creative learning process is being able to identify problems, weaknesses, gaps in knowledge, absence of elements, inconsistencies, and then gathering available information; identifying deficiencies, searching for solutions, testing and retesting these solutions until reaching the perfect ones; and in the end, reaching the results. Likewise, Taylor (1974) described the creative process as the elaboration of creative actions that will eventually lead to the production of creativity. Wallas (1926) defined four steps of the creative process: preparation, incubation, illumination, and verification, which led to the development of Creative Problem Solving Model. This model dealt with teaching individuals to find and determine the problem, then gathering the necessary information and developing creative ideas about the possible solutions (Meadow \& Parnes, 1959; Meadow, Parnes, \& Reese, 1959).

Rauth, Köppen, \& Meinel, (2010) and Carroll, Goldman, Britos and Koh (2010) showed that the type of content along with the type of pedagogy contribute to different levels of creativity creative knowledge and creative skills. As suggested by Fink, 2007, as cited in Hardiman, 2010, activities associated with creative thinking produce differentiated patterns of activity across multiple regions of the brain The co-activation and communication among brain regions that are not ordinarily strongly connected during noncreative activities (Heilman et al, 2003, as cited in Hardiman, 2010) can now be stimulated by immersing learners in processes which encourage them to demonstrate divergent thinking through allowing them for multiple representations of the material freeing them from being constrained to memorize books and to adhere to teachers' instructions.

In his book, Gebhard (2006) offers some methods to improve EFL teachers' skills to enhance students' creativity. He focused on teaching English in a communicative way. His method depends on teaching students to comprehend spoken English and to conduct open dialogues among students. Additionally, he emphasizes that these activities must not be separated from the cultural context and must be integrated with the cultural elements to enhance creative thinking, an argument also supported by Raba (2014). Copeland (2005) illustrates that students are surrounded by certain type of exams and expected to give predetermined answers, and suggests Socratic circles as a technique to guarantee that discussions are managed by students. Moreover, open dialogues circles strategy develops students' thinking skills to become more effective individuals. Students will respect differences among them and work harmoniously.

Another aspect of fostering creativity involves bringing playing activities into the classroom. Many researchers have argued in favor of play strategies as a tool for enhancing creativity. Craft (2003) asserts that "play is necessary to creativity, not all play is creative" (p. 150). As a result, teachers should clearly set the purpose of play techniques and their effect in promoting 
creativity. The aim of such activities is to empower students' imagination and to have novel perspectives. The ability to analyze a given issue from multiple perspectives and reconstruct the available knowledge is fundamental for those creative thinkers to accomplish their objectives (Mumford, 1984). Besides, Torrance (1972) illustrated that creativity growth includes both cognitive and affective characteristics. If affect is merged with imagination, creativity will increase: "the ability to think imaginatively in a free-association style and to be open to thinking about affect-laden material being related processes" (Suler, 1980, p.770). What kills creativity according to Hennessey and Amabile (1987) is using restricted situation choices. When students abide to the choices offered by the teacher to deal with situations they encounter, no space for creative thinking is allowed. In addition, much surveillance over students' work would make them hesitate to try new ideas. Also, focusing students' attention on expected evaluation or expected reward would minimize their motivation. If students focus on the idea that they are learning to perform an exam, this would strip the joy out of the learning process and replace it with anticipation and fear. All of the previously mentioned practices would paralyze students' imagination and their motives to try and experiment with new things.

\section{Creative thinking in Palestinian curricula and schools, and creative thinking in math and English lessons.}

Romahi and Issa (2010) emphasized how the atmosphere hindered appropriate teaching and wishful learning. They added that since the establishment of the Palestinian Ministry of Education, it was tasked with the enormous duty of setting up an educational system from 'scratch'. Reform followed specifically in 2008 with the development of the educational strategic plan aimed at reforming shortfalls in the education system. The current system however, still struggles to bring about educational reform in a climate of instability, and unexpected change which would be a strong obstacle in all subjects to hinder creative thinking in a good way.

Hamdona (2007) found that the lowest score is critical thinking life skills domain which got $10.54 \%$ out of the total average of the five domains. Items such as "identifying relevant information, organizing thoughts to reflecting logical thinking and thinking of different ways to answer a question" have great interest in training learners how to think. However, the textbook exercises neglect or ignore items such as "applying of technology, confident in reaching a reasonable conclusion and finding answers to challenging questions" Additionally, the next low scores were fore decision-making / problem solving life skills domain that got 13.2\%, consequently, the research could focus on the connection between textbooks and life skills in order to build up good citizens who benefit their countries. The inclusion of Critical thinking and leadership life skills are new dimensions and trends.

Hamouda (2009) recommended the inclusion of texts and stories that emphasize mental educational values; he added that the books activities should incorporate students' thinking, insight and wit, verification and preservation of time. Here, the researcher showed how important is the work of the textbook designer in the inclusion of very suitable texts in English and other subjects. 
Abu Shams (2003) showed that An-Najah English majors and instructors need more training in using Cognitive, Memory and Compensation strategies by embedding them into regular classroom activities. The researcher here emphasized the importance of both pedagogy content in improving high thinking skills, that is, not only the rich content is vital in teaching thinking, but also effective teachers are basic in this context

Abu Ashiba (2010) Recommended to make balance in distributing the values in the content of the textbook including all types of cognitive skills such as creative thinking skills and critical thinking skills. Therefore, the researcher also recommended holding workshops in order to discuss all types of activities that enhance the balance of all the values included in the textbook of English for the twelfth grade.

Abu Tailakh (2015) recommended modifying the reading activities by providing them with enrichment material that included creative thinking skills, decision -making activities and problem-solving exercises. English language supervisors and principals are also recommended to hold more workshops to train English language teachers on how to enhance the creative thinking skills in the pupils' mentalities.

Naser, Nafi' and Arman (2016) showed that the degree of faculty's use and stimulation of critical thinking skills in the English Department were medium, and that there were no statistically significant differences in the degree of the faculty's use and stimulation of critical thinking due to gender and performance, and the presence of significant differences was due to level and in favor of third year English majors. The results of the students' interview also showed that there were skills that teachers used largely as the skill of interpretation and analysis, and that there were skills which were fairly used such as the skill of inference, and the assessment skill was low.

According to Shehadeh and Dwaik (2013) teaching English in Palestine is influenced by many factors (e.g. large number of students in each class, the limited class period time, the few number of classes each week, etc.) which limit the extent of creativity and teachers' ability to deal with students individually. Also, the lack of technological resources to be used in classes and depending too much on textbooks restricts the number of activities used creatively to teach the language communicatively.. When students do not get enough attention due to their large number in each class it leaves them no opportunity to practice the language or communicate in it (Dajani \& Mclauplin, 2009). The teacher-centered approach in the process of teaching remains the only possible approach where they depend on textbooks as the only tool of teaching and in the absence of a challengeable atmosphere, students do the exercises in a dull and routine way without any effort for creativity as summarized by Fennel (2007) English classes are designed only to suit the standardized tests.

In the area of creative thinking in Math in the Palestinian context, studies are few and not adequate; some studies were done in the area. For example, Zamel, (2011) and Attakaineh 
(2011) concluded that what hinders creative thinking skills in Math classroom practices include crowded classes, teachers' concern of finishing textbook, lack of time to apply collaborative activities that promote creative thinking among students. They recommended reducing the number of classes in addition to holding more and more training workshops for teachers of Math on helping students have more practice in using creative and thinking

In a seminar held in the educational Qattan Centre for Educational Research and Development, addressing a group of secondary school students' views on the most important educational problems faced by secondary stage, students put a blame on their teachers and management for not respecting them as adults. Students mentioned that teachers do not understand their personal and educational needs including appropriate thinking skills, decision thinking skills and problem solving skills, particularly in these difficult circumstances that encounter the educational sector. (Wahba, 2001:37)

Khalid A (2014) concluded that the higher thinking skills in Math are included moderately, and the study recommended the need to take advantage of higher thinking skills list specified in the current study, as well as reviewing the adequacy of the examples and exercises included in the books of Mathematics for the basic stage for each skill.

Palestinian students participated in the TIMSS 2003 and 2007 assessments in Math and science. In both years, students were assessed in grade 8. Palestine's purpose in participating in the study was to obtain achievement indicators that could be used for comparison within the international context. Although results were not high compared with the results of other countries, the Ministry of Education and Higher Education viewed TIMSS as a "diagnostic tool" for educational reforms, development of new curriculum, teachers training and introduction of some form of certification or licensing of teachers. In an attempt to minimize the problems in the area of teaching English and Math, the present study sought to answer these questions:

1) To what extent do schools English and Math curricula enhance creative thinking in learning?

2) Are there significant differences at $(p=0,05)$ in the degree of teachers' opinion about the extent of schools enhancing creativity with reference to specialization, gender, qualification and years of experience?

Methodology

Before starting with methodology, it is worth mentioning some background knowledge about the Palestinian context. In terms of history, formal education in Palestine has been controlled and administered by foreign rule. Let's start from the 1917 during British rule, education was expanded to supply a growing need for civil servants for the British Empire (Barakat, 2007; Brown, 2003a). As a result, education came to be associated with the power structures and the ruling elite. In 1948 Palestinian education continued to deteriorate with the creation of the state of Israel and the ethnic cleansing of the majority of the indigenous population. Palestinian refugees in UN-administered camps were subject to the educational policies and curricula of the host countries (Hanafi, Hilal \& Takkenberg, 2014). In the West Bank and Gaza Strip, Jordan and Egypt respectively applied their national curricula. Accordingly, formal education received by Palestinians was not concerned with preserving Palestinian historic-cultural distinctiveness or 
advancing political and social aspirations (Brown, 2003a). During the Israeli occupation of the West Bank and Gaza in 1967, military authorities targeted the education system (Abo Hommos, 2013; Asaad, 2000). Things became worse during the intifada civil protest movement starting in 1987, when Israeli military forces closed down schools and universities for periods of up to two years. The adverse impact on Palestinian education was enormous.

Education under Palestinian Self-rule The 1993 Oslo Peace Accords The first-ever Palestinian Ministry of Education (MoE) was established in 1994 with the remit to prepare an aspirant Palestinian citizenry for institution building, state formation and the global information economy. This entailed rebuilding an outdated educational system with severe shortages of qualified teachers and school buildings, and an outdated foreign curriculum. Suffering and oppression continued resulted in the failure of The curricula and teaching pedagogies in to enhance critical thinking and the capacity to apply logic amongst the students from variable age categories. Based on this continual bleeding of the Palestinian Education, the researcher tried find a way that might help to reform the educational system.

The forthcoming paragraphs deal with population and sample, instrumentation, credibility and reliability, procedures and statistical processes.

The study population consisted of all English language teachers and math teachers in Nablus Government City schools.(120 male and female teachers of English and Math : 70 male and female teachers of English and 50 male and female Math teachers according to the directorate of Education statistics.

The sample of the study which was simple and random, consisted of (14) male and female teachers (8) teachers of English and (6) teachers of Math which represented $11.6 \%$ of the whole population). All the names of the 120 teachers were written on completely duplicated scraps of paper, folded and mixed well and then the 14 male and female teachers were randomly chosen; this type of choice is simple; so the sample was simple and random. Table 1 shows the result of the distribution of the sample according to the study independent variables

Table 1.

The distribution of the sample by independent variable

\begin{tabular}{llll} 
Variable & Level & Frequency & Percentage \\
\hline Specialization & English language & 8 & 57.2 \\
& Math & 6 & 42.8 \\
Gender & Male & 5 & 35.7 \\
& Female & 9 & 64.3 \\
Qualification & B.A & 8 & 57.1 \\
\multirow{2}{*}{ Years of Experience } & M.A & 6 & 42.9 \\
& Less than 5 years & 10 & 71.4 \\
Total & From 5-10 years & 4 & 28.6 \\
& & $\mathbf{1 4}$ & $\mathbf{1 0 0 . 0}$
\end{tabular}

\section{Instrumentation}


The researchers used two tools: An interview in addition to a 20-item questionnaire for collecting data necessary for the purpose of the study. The tools were developed by the researchers after surveying previous relevant studies in the same area.

\section{Credibility and Reliability:}

The study tools were given to experts in the field of the study area. They deleted three items and so the total items of the questionnaire become 20; they also modified some items until the study instruments reached final forms. To determine the reliability of three sub-questionnaires, Chronapach Alpha formula was used. It was $(0.83)$, this value is suitable for conducting such a study.

To analyze the data necessary for the study variables the researchers used the Statistical Package for Social Science (SPSS) version 20. They also used frequencies, means, standard deviations and percentages. Additionally, they used Chronapach Alpha formula, T- test for two independent samples, and One Way ANOVA test.

\section{Results of the study}

Table 2 shows the results obtained for the first question "What is the degree of teachers" agreement on the extent that schools enhance creative thinking skill in EFL and math classes? "

Table 2.

Means, standard deviations, percentages and estimation level

\begin{tabular}{|c|c|c|c|c|c|c|}
\hline$\frac{c}{2}$ & 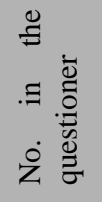 & $\stackrel{\Xi}{\Xi}$ & $\stackrel{\Xi}{\Sigma}$ & 苛 & 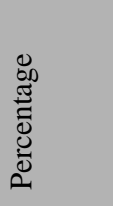 & 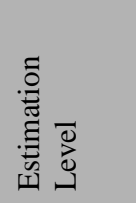 \\
\hline 1 & 1 & $\begin{array}{l}\text { School encourages everything new } \\
\text { in the teaching- learning process }\end{array}$ & 3.07 & 0.73 & 61.4 & Moderate \\
\hline 2 & 10 & $\begin{array}{l}\text { Class management develops creative } \\
\text { thinking among students }\end{array}$ & 3.07 & 0.47 & 61.4 & Moderate \\
\hline 3 & 6 & $\begin{array}{l}\text { Creativity practices in schools are } \\
\text { encouraged }\end{array}$ & 3.07 & 0.73 & 61.0 & Moderate \\
\hline 4 & 9 & $\begin{array}{l}\text { School library is rich in books that } \\
\text { enhance creative thinking }\end{array}$ & 3.02 & 0.91 & 60.4 & Moderate \\
\hline 5 & 5 & $\begin{array}{l}\text { Content limits teaching; still } \\
\text { methodology is up to the teacher }\end{array}$ & 3.01 & 0.66 & 60.2 & Moderate \\
\hline 6 & 7 & $\begin{array}{l}\text { School has clear strategy about } \\
\text { creative teaching }\end{array}$ & 3.00 & 0.80 & 60.0 & Moderate \\
\hline 7 & 2 & School supports students' activities & 3.00 & 0.75 & 60.0 & Moderate \\
\hline 8 & 8 & $\begin{array}{l}\text { Teachers are free to teach creative } \\
\text { ideas }\end{array}$ & 2.35 & 1.21 & 47.0 & Very low \\
\hline
\end{tabular}




\begin{tabular}{|c|c|c|c|c|c|}
\hline 94 & $\begin{array}{l}\text { School gives teachers autonomy in } \\
\text { their own classrooms }\end{array}$ & 2.35 & 1.08 & 47.0 & Very low \\
\hline $\begin{array}{ll}1 & 3 \\
0 & \end{array}$ & School gives creative homework & 2.07 & 1.07 & 41.4 & Very low \\
\hline Total & of the first domain (School) & 2.71 & 0.42 & 52.4 & Low \\
\hline
\end{tabular}

Table (1) shows that the total degree of teachers' agreement on the extent that schools enhance creative thinking skill in English and math classes was 52.4\% which can be considered low. The highest percentage (61.4\%) was found for each of the following items: "School encourages everything new in the teaching-learning process", and "Class management develops creative thinking among students," and "There is some concern about creativity and innovation in schools ". On the other hand, the lowest percentage was found for the item "School gives creative homework activities" with41.4\%)

Table 3.

Means, standard deviations, percentages and estimation level

\begin{tabular}{|c|c|c|c|c|c|c|}
\hline Z & 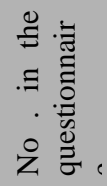 & Е & $\underset{\Xi ี}{\stackrel{\Xi}{\Sigma}}$ & $\frac{\mathscr{0}}{.0}$ & 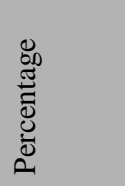 & 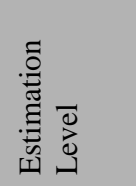 \\
\hline 11 & 11 & Objectives have creative outputs & 3.37 & 0.82 & 67.4 & Moderate \\
\hline 12 & 12 & $\begin{array}{l}\text { Content is in line with creative thinking } \\
\text { skills }\end{array}$ & 3.22 & 0.67 & 64.4 & Moderate \\
\hline 13 & 14 & Curricula challenge the students' abilities & 3.20 & 0.80 & 64.06 & Moderate \\
\hline 14 & 20 & Curricula encourage intelligence & 3.18 & 0.82 & 63.6 & Moderate \\
\hline 15 & 15 & Contents is rich in high knowledge skills & 3.14 & 1.00 & 62.8 & Moderate \\
\hline 16 & 13 & $\begin{array}{l}\text { Contents meets the students' real life } \\
\text { situations }\end{array}$ & 3.14 & 0.84 & 62.8 & Moderate \\
\hline 17 & 16 & $\begin{array}{l}\text { Content is more theoretical than practical } \\
\text { ones }\end{array}$ & 3.10 & 1.00 & 62.0 & Moderate \\
\hline 18 & 18 & $\begin{array}{l}\text { Curricula motivate students to think } \\
\text { rather than to memorize }\end{array}$ & 3.07 & 1.34 & 61.4 & Moderate \\
\hline 19 & 17 & $\begin{array}{l}\text { Curricula make the learning student- } \\
\text { centered }\end{array}$ & 3.00 & 1.15 & 60.0 & Moderate \\
\hline 20 & 19 & $\begin{array}{l}\text { Curricula concentrate on creative } \\
\text { questions }\end{array}$ & 3.00 & 0.85 & 60.0 & Moderate \\
\hline \multicolumn{3}{|c|}{ Total degree of the second domain (Curricula) } & 3.11 & 0.55 & 62.2 & Moderate \\
\hline
\end{tabular}

Table (2) shows that the total degree of teachers' agreement on the extent that schools enhance creative thinking skill in EFL and math classes according to EFL teachers' perspectives for the second domain (Curricula) was (62.2\%) which suggests a moderate level of agreement. The highest percentage was identified for the items "Curricula objectives have creative outputs" which received $67.4 \%$, but it is still a moderate level. On the other hand, the lowest percentage was found for the item "Curricula concentrate on creative questions," which received $60.0 \%$, and this means that the textbooks lack effective questions that really enhance learners' thinking skills.

Results of the second study question "Are there statistical significant differences $(\alpha=0.05)$ about EFL teachers' opinions about the extent that schools enhance creative thinking skill in EFL and 
math classes attributed to the variable of specialization, gender, qualification and years of experience? To answer this question, t- Test for Independent Samples and One Way ANOVA tests were used; tables $(3,4,5$ and 6$)$ show the results.

\section{Table 4.}

Independent sample t test results of EFL teachers' opinions by specialization

$\begin{array}{lllllll}\text { Total Degree } & \text { Specialization } & \text { N } & \text { Mean } & \text { S. D } & \text { T } & \text { Sig.* } \\ & \text { English language } & 8 & 3.12 & 0.28 & 0.275 & 0.210 \\ & \text { Math } & 6 & 3.20 & 0.31 & & \end{array}$

*. The mean difference is significant at the 0.05 level.

Table 5.

Independent sample t test results of EFL teachers' opinions by gender

$\begin{array}{lllllll}\text { Total Degree } & \text { Gender } & \text { N } & \text { Mean } & \text { S. D } & \text { T } & \text { Sig.* } \\ & \text { Male } & 5 & 3.07 & 0.31 & -1.780 & 0.100 \\ & \text { Female } & 9 & 3.25 & 0.41 & & \end{array}$

*. The mean difference is significant at the 0.05 level.

Table 6.

Independent two sample t test results of EFL teachers' opinions by qualification

$\begin{array}{lllllll}\text { Total Degree } & \text { Qualification } & \text { N } & \text { Mean } & \text { S. D } & \text { T } & \text { Sig.* } \\ & \text { B.A } & 8 & 3.04 & 0.47 & 0.297 & 0.772 \\ & \text { M.A } & 6 & 3.17 & 0.36 & & \end{array}$

*. The mean difference is significant at the 0.05 level.

Table 7.

Independent sample t test results of EFL teachers' opinions by experience

$\begin{array}{lllllll}\text { Total Degree } & \text { Experience } & \mathrm{N} & \text { Mean } & \text { S. D } & \text { T } & \text { Sig.* } \\ & 1-5 & 10 & 3.11 & 0.43 & 1.423 & 0.180 \\ & 6-10 & 4 & 3.17 & 0.24 & & \end{array}$

*. The mean difference is significant at the 0.05 level.

The above Tables show that there are no statistically significant differences $(\alpha=0.05)$ among the teachers about the extent that schools enhance creative thinking skill in English and math classes by the independent variables of specialization, gender, qualification and experience.

\section{Results of the second study tool (Interview)}

Five teachers (3 English, 2 Math) were randomly chosen and interviewed about the extent of schools English and Math curriculum enhancing of creative thinking skills in EFL and math classes; they agreed that schools do not encourage everything creative and new in the teaching and learning process. They also agreed strongly that the curricula lack strategies for developing creative thinking among the students. These results are in line with those of the questionnaire regarding the role of school in enhancing creative thinking among students. The same result was 
found about the curricular objectives in the field of creative thinking. Moreover, supporting the questionnaire results, the interviewees were negative about the appropriateness of the curricula to the students' creativity needs. They agreed that curricula do not meet the needs of their students in the teaching-learning process. Additionally, they agreed that the Role play technique could be used in classroom to enhance students' imagination and self-esteem. In addition, some of them suggested forming student discussion groups and debates to make students participate more keenly and in a more engaged fashion. They reinforced their responses by mentioning that training sessions could be conducted for the same subject for both teachers and students to ensure success.

\section{Discussion}

According to the teachers, schools do not encourage everything new, and class size and management restrict creative thinking. Students are not given the chance to think out of the box in different ways. This can be attributed to the administrative regulations requiring teachers to cover the course material. They do not have enough time to apply strategies such as role-play, problem solving, and brain storming that enhance students' thinking skills. Teachers are in a real race to finish the heavy and usually overloaded content. We think that both the English and math curricula lack activities that really challenge students' high thinking skills. So, as a solution for this, supplementary materials derived from real life situations can be included in classroom teaching, and the homework items can be carefully selected to complete the missing link of the curricula to the life outside the school. In the Curriculum, students should develop capability in critical and creative thinking, and so they should learn to generate and evaluate knowledge, clarify concepts and ideas, seek possibilities, consider alternatives and solve problems. Critical and creative thinking should be integral to activities that require students to think broadly and deeply using skills, behaviors and dispositions such as reason, logic, resourcefulness, imagination and innovation in all learning areas at school and in their lives beyond school. (Raba' and Dweikat, 2017).

Special attention should be directed to the selected content of the subject which plays a key role to attract students' attention, and encourage them to think more creatively. The teachers' responses show no statistically significant differences in their opinions regarding the extent that schools enhance creative thinking skill in EFL classes based on the variables of specialization, gender, qualification and years of experience. These results can be attributed to the lack of new methods of teaching, particularly in the field of teaching and learning languages. In addition, the progressive development of knowledge about thinking and the practice of using thinking strategies can increase students' motivation for, and management of, their own learning. They become more confident and autonomous problem-solvers and thinkers. Further studies about using modern or innovative methods of teaching might reveal the importance of such new approaches. As the Educational Palestinian context is so much different from almost all the educational contexts all over the world due to the different sequential foreign occupations starting from the Othmani rule until the Israeli occupation that is over a century and a half, all the national attempts are inadequate to recover the bleeding wound. Struggle to free the curriculum and make it pure national without the effect of the Israeli continual domination continues hoping that effort and time to be directed for education and producing good generation capable to 
compete with other nations in the world. This is in accordance with countries Hanafi, Hilal \& Takkenberg, 2014).

\section{Recommendations}

Many researchers have attempted to find out methods to enhance creativity in teaching. For instance, Myers and Torrance (1961) found that rewarding creative thinking in children, which brings marvelous results in creative thinking and information processing enhancement. Hennessey and Amabile (1987) offer some tips to enhance creative attitudes in the classroom: (1) students are most creative when they enjoy what they are doing, (2) avoid using tangible rewards; (3) don't construct competitive tasks; (4) encourage children to keep track of their own work; (5) encourage children to develop their self-esteem and to concentrate on their strengths; (6) let students feel the value of creativity.

Based on the study results, the following are recommended for practice:

1. New teaching trends that foster creativity should be included in the curricula including dialogue, reflection, collaboration and action; these serve to enhance individual and collective agency, and communal ties in preparation for strategic collective action.

2. Extensive lessons with new teaching methods should be designed in a way to increase students motivation and participation in the classroom.

3. Teachers should be trained well in order to master the new developments in teaching to foster creativity.

4. Imaginative activities and creative assignments (eg. Role play) which suit students' levels and needs should be particularly emphasized in the teaching process. 


\section{References}

Abu Ashiba, S (2010). An Analysis of the Incorporated Values in English for Palestine 12 The Islamic University of Gaza. Unpublished thesis.

Abo Hommos, N. (2013). PA The Day After: Collapse and its Effect on Education, Palestinian Center for Policy and Research, Ramallah: The Palestinian Centre for Policy and Survey Research.

Abu Shams, W. (2003). Language Learning Strategy Use in Palestine. The Electronic Journal for English as a Second Language, 7(2), 1-13.

Abu Tailakh (2015). Creative Thinking Skills in the Reading Activities of English for Palestine 8: An Evaluation Study. AL-Azhar University -Gaza. M.A Thesis

Anderson, J. V. (1994). Creativity and play: A systematic approach to managing innovation. Business Horizons, 37, 80-85.

Attakaineh. B. H. (2011). The Effect of Using Strategy Based on Dimension of Learning on Attitudes and Mathematical Communication skills of special education schools district. Islamic University Journal, 19(1), 399-426. Retrieved Sep. 27, 2012, from http://www.iugaza.edu.ps/ar/periodical/

Asaad, D. (2000). Palestinian educational philosophy between past and present, Studies in Philosophy and Education 19, (5-6), 387-403.

Ayat, A. (2012). Evaluating the Higher Order Thinking Skills in Reading Exercises of English for Palestine Grade 8. Unpublished Master Thesis, Islamic University, Gaza, Palestine

Barakat, B. F. (2007). The struggle for Palestinian national education past and present. C. Brock and L. Z. Levers (Eds). Aspects of Education in the Middle East and North Africa. Oxford: Symposium Books.

Barron, F. (1955). The disposition toward originality. Journal of Abnormal Psychology, 51, 478485.

Brown, N. J. (2003a). Democracy, history and the contest over the Palestinian Curriculum. Cairo Papers in Social Science 25(4).

Carroll, M., Goldman, S., Britos, L., Koh, J., Royalty, A., \& Hornstein, M. (2010). Destination, Imagination and the Fires Within: Design Thinking in a Middle School Classroom. International Journal of Art \& Design Education, 29(1), 37-53.

Chen, M. (2010). Education Nation: Six Leading Edges of Innovation in our Schools. San Francisco, CA: Jossey-Bass.

Copeland, M. (2005). Socratic Circles: Fostering Critical and Creative Thinking in Middle and High School

Cotton, K. (1991). Teaching Thinking Skills. North West Regional Educational Laboratory, School Improvement Program.

Craft, A. (2003). Creative thinking in the early years of education. Early Years: Journal of International Research \& Development, 23, 143-154.

Cropley.a. j (1992). More Ways than One: Fostering Creativity

Csikszentmihalyi, M. (1996). Creativity: Flow and the psychology of discovery and invention. New York: HarperCollins.

Dajani.D and McLaughlin (2009). Implementing the first Palestinian curriculum: A need for teachers' empowerment. Mediterranean journal of educational studies. 
Elder, L. (2007). A brief conceptualization of critical thinking. Retrieved August 21, 2012 from http://www.criticalthinking.org/pages/defining-critical-thinking/410/.

Fennil. M. (2009). Contradiction in the construction of 'teacher-self': a case study in the secondary English language teachers in a majority world context.

Freire, P. (1995). Pedagogy of the Oppressed. New York: Continuum. pp. 52-67.

Friesen, S. \& Jardine, D. (2010). 21st Century Learning and Learners. In Government of Alberta. from education.alberta.ca/.../wncp\%2021st\%20cent\%20learning\%20(2).pdf.

Gebhard (2006). Teaching English as a Foreign or Second Language, Second Edition. A Teacher Self-Development and Methodology Guide. Michigan Teacher Training. University of Michigan.

Hamdona, Y. (2007). Life Skills Latent in the Content of English for Palestine - Grade Six Textbook the Islamic University of Gaza. Unpublished MA Thesis

Hammad, E (2014). Palestinian EFL Teachers' Attitudes towards English Textbooks Used at the First Three Grades of Elementary School. The Electronic Journal for English as a Second Language Volume 18, Number 1

Hamouda, M. (2009). "Educational values incorporated in the stories of the Palestinian curriculum in key stage in the light of the Supreme Islamic educational thought" Unpublished thesis.

Hanafi, S., Hilal, L. and Takkenberg, L. (2014). UNRWA and Palestinian Refugees: From Relief and Works to Human Development. Abingdon, Oxon: Routledge.

Hardiman, M. (2010). The Creative-artistic Brain. In Souza, D. (Ed.), Mind, Brain, and Education: Neuroscience Implications for the Classroom. Bloomington, IN: Solution Tree.

Jarwan, F. (2007). Teaching Thinking Concepts \& Applications. 3rd ed., Dar el fikr, Amman, Jordan.

Khalid A (2014). The Higher Thinking Skills in Math for the Basic Stage in Palestine from the Perspective of Teachers. IUG Journal of Educational and Psychological Studies, 22(1), 3154.

Larsen, J. (2002). The Promotion of Social Acceptance of Students with Learning Disabilities through Friendship Skill Training Disability Awareness, California State University, Fullerton, USA

Lubart, T. I. (1990). Creativity and cross-cultural variation. International Journal of Psychology, 25, 39-59.

MacKinnon, D. W. (1962). The nature and nurture of creative talent. American Psychologist, 17, 484-495.

McWilliam, E. (2009). Teaching for Creativity: From Sage to Guide to Meddler. Asia Pacific Journal of Education, 29(3), 281 - 293.

Magno, C. (2009). Explaining the creative mind. International Journal of Research \& Review, 3, 10-19. Mumford, M. D. (1984). Age and outstanding occupational achievement: Lehman revisited. Journal of Vocational Behavior, 25, 225

Meadow, A., \& Parnes, S. J. (1959). Evaluation of training in creative problem solving. Journal of Applied Psychology, 43, 189-194. http://dx.doi.org/10.1037/h0046040

Meadow, A., Parnes, S. J., \& Reese, H. (1959). Influence of brainstorming instructions and problem sequence on a creative problem solving test. Journal of Applied Psychology, 43, 413-416. http://dx.doi.org/10.1037/h0043917

Myers, R. E., \& Torrance, E. P. (1961). Can teachers encourage creative thinking? Educational Leadership, 19, 156-159. 
Naser, I; Nafi'J and Arman, I (2016). The Degree of Faculty's Use and Stimulation of Students' Critical Thinking from the Perspective of English Majors at Al-Quds University. Journal of Education and Practice, 7(29), 35-44.

Raba' Ahmed and Dweikat K (2017). Teachers' Perspectives of the Influence of Homework Assignments on Students' Achievement. Journal of Social Science and Humanities. Asian Academic Research. Vol 4(9) 271-294.

Raba' Ahmed (2014). The Importance of Integrating the Target Culture in English Language Teaching from the Teacher's Perspectives. Al- Qasmi Academy (RA). Academy College of Education, 18(1), 1-30.

Rauth, I., Köppen, E., \& Meinel, C. (2010). Design Thinking: An Educational Model towards Creative Confidence. Proceedings of the 1st International Conference on Design Creativity ICDC 2010 (to appear).

Romahi and Issa (2010). Assessing the Educational System in Palestine: An NGO Perspective. Context, Problems, Challenges and Policy Recommendations. Teacher Creativity Centre, Ramallah. Palestine

Shehadeh, A and Dwaik, R. (2013). The Practice of Teaching English to Young Learners in the Palestinian Context: A Multidimensional Analysis. Arab word English journal.

Suler, J. R. (1980). Primary process thinking and creativity. Psychological Bulletin, 88, 144-165. Sternberg, R.J. (1999). Handbook of creativity.

Tarman, B. (2017). Editorial: The Future of Social Sciences. Research in Social Sciences and Technology, 2(2). Retrieved from http://ressat.org/index.php/ressat/article/view/329

Tarman, B. \& Chigisheva, O . (2017). Editorial for Special Issue: Transformation of Educational Policy, Theory and Practice in Post-Soviet Social Studies Education. Journal of Social Studies Education Research, 8 (2), i-iv. Retrieved from http://dergipark.gov.tr/jsser/issue/32450/360860

Tarman, B., Baytak, A., \& Duman, H. (2015). Teachers' views on an ICT reform in education for social justice. Eurasia Journal of Mathematics, Science and Technology Education, 11(4), 865-874. 10.12973/eurasia.2015.1445a

Taylor, I. A. (1974). Developing creativity in gifted young adults. Education, 94, 266-268.

Torrance, E. P. (1972). Predictive validity of the Torrance Tests of Creative Thinking. The Journal of creative behavior, 6, 236-262.

Torrance, E. P., \& Myers, R. E. (1970). Creative learning and teaching. New York, NY: Dodd, Mead \& Company. - 244.

Wallas, G. (1926). The art of thought. New York: Harcourt Brace Jovanovich.

Whaba, N. (2001). "Views of the students in (s) secondary school" Educational sights, p, 37-39.

Yücel, C., Acun, I., Tarman, B., \& Mete, T. (2010). A model to explore Turkish teachers' ICT integration stages. Turkish Online Journal of Educational Technology, 9(4), 1-9.

Zamel, M. (2011). The Obstacles Facing the Palestinian Teacher in Developing Creative Thinking Skills inside the Classroom in U.N.R.W.A Schools. The Journal of Educational \& Psychological Sciences (JEPS) University of Bahrain 


\section{Appendix}

\section{Questionnaire}

Dear Teacher:

The questionnaire was designed to investigate the "To What Extent Do Schools Enhance Creative Thinking Skill in EFL and Math Classes According to Teachers' Perspectives" Please, read all the questions carefully and then tick the correct option which you consider. Your answer will confidential and will only be used for research purposes

Thank you for your cooperation.

Researchers:

Section (1): Personal Information

1) Gender: $\quad \square$ Male $\quad$ Female $\square$

2) Qualification: $\square$ B.A M.A

3) Experience: $\square$ 1-5 6-10 $\square$ More $\square$

Section (2): Read the following statements carefully and check under the column that best represent your level of agreement with each statement

A: School

\begin{tabular}{|c|c|c|c|c|c|c|}
\hline$\dot{0}$ & $\stackrel{\Xi}{\Xi}$ & 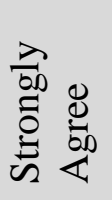 & 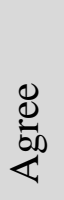 & 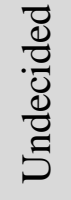 & 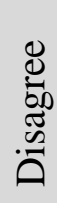 & 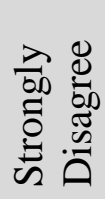 \\
\hline 1. & $\begin{array}{l}\text { School encourages everything new in the teaching- } \\
\text { learning process. }\end{array}$ & & & & & \\
\hline 2. & $\begin{array}{l}\text { School policy makes scientific competitions between } \\
\text { students }\end{array}$ & & & & & \\
\hline 3. & School gives enough time for students' activities & & & & & \\
\hline 4. & $\begin{array}{l}\text { School gives teachers autonomy in their own } \\
\text { classrooms }\end{array}$ & & & & & \\
\hline 5. & $\begin{array}{l}\text { Content limits teaching; still methodology is up to a } \\
\text { teacher to decide }\end{array}$ & & & & & \\
\hline 6. & Creativity and innovation in schools are concerned & & & & & \\
\hline 7. & School has clear strategy about creative teaching & & & & & \\
\hline 8. & Teachers are free to apply the creative ideas. & & & & & \\
\hline 9. & $\begin{array}{l}\text { School library has books and references which enrich } \\
\text { creative thinking among students. }\end{array}$ & & & & & \\
\hline
\end{tabular}




\begin{tabular}{|l|l|l|l|l|l|l|}
\hline 10. & $\begin{array}{l}\text { Class management develops creative thinking among } \\
\text { students. }\end{array}$ & & & & & \\
\hline
\end{tabular}
B: Curricula

\begin{tabular}{|c|c|c|c|c|c|c|}
\hline$\stackrel{\dot{z}}{ }$ & 巳ี & 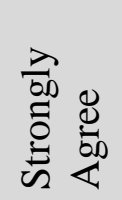 & $\begin{array}{l}\stackrel{8}{0} \\
\underset{0}{0}\end{array}$ & 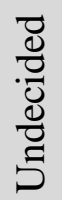 & 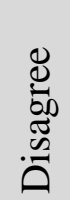 & 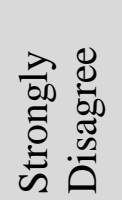 \\
\hline 11. & Curricula objectives have creative outputs. & & & & & \\
\hline 12. & $\begin{array}{l}\text { Curricula contents are in line with creative thinking } \\
\text { skills. }\end{array}$ & & & & & \\
\hline 13. & $\begin{array}{l}\text { Curricula contents meet the students' real life } \\
\text { situations. }\end{array}$ & & & & & \\
\hline 14. & $\begin{array}{l}\text { Curricula are rich in creative activities which } \\
\text { challenge the students' abilities. }\end{array}$ & & & & & \\
\hline 15. & Curricula contents are in high knowledge skills. & & & & & \\
\hline 16. & $\begin{array}{l}\text { Curricula are in theoretical sides rather than practical } \\
\text { ones. }\end{array}$ & & & & & \\
\hline 17. & $\begin{array}{l}\text { Curricula make the learning - teaching process } \\
\text { student- centered. }\end{array}$ & & & & & \\
\hline 18. & $\begin{array}{l}\text { Curricula motivate students to think rather than to } \\
\text { memorize. }\end{array}$ & & & & & \\
\hline 19. & Curricula concentrate on creative questions. & & & & & \\
\hline 20. & $\begin{array}{l}\text { Curricula encourage students to develop their } \\
\text { intelligence. }\end{array}$ & & & & & \\
\hline
\end{tabular}

